\title{
Merkityksiä odotuksen tilassa (Le sens suspendu)
}

KAVI ja Aalto ARTS (Elokuvataiteen ja lavastustaiteen laitos \& Taiteen laitos) järjestivät yhteistyössä 8.10.2016 "Leikkisä Work in Progress" -seminaarin Jacques Rivetten kokeellisen teoksen Out1 ympäriltä. Seminaarin tarkoituksena oli pohtia ilmaisun ja muodon ulottuvuuksia muun muassa ensemble-työskentelyyn eri taiteen aloilla perehtymällä. Oheinen Suzanne Liandrat-Guiguesin luento toimi johdantona Jacques Rivetten taiteeseen ja elokuvaan Out1. Ensemble-työskentelystä kirjallisuuden ja elokuvan osalta puhuivat Turun yliopiston tutkija Tiina Käkelä-Puumala Mahdollisen Kirjallisuuden Seurasta ja näyttelijäntyön professori Elina Knihtilä Taideyliopiston teatterikorkeakoulusta. Tilaisuuden päättivät professori Harri Laakso Aalto ARTS:in Taiteen laitokselta ja post doc-tutkija Maiju Loukola elokuvataiteen ja lavastustaiteen laitokselta. He kertoivat Jacques Rivetten Out1-elokuvan inspiroimasta kurssista "Out2 - Collective film in the spirit of Jacques Rivette", joka järjestettiin Aalto ARTS:issa syksyllä 2016. Toinen tässä Lähikuvan numerossa julkaistu katsaus "Out 2 - kokeellinen liikkuvan kuvan kollektiiviteos nykyisen ja menneen ajan leikkauspisteitä jäljittämässä" avaa kurssia ja sen tuloksia tarkemmin.

Tammikuussa 2016 Pariisissa kuollut Jacques Rivette oli syntynyt Rouenissa vuonna 1928. Hän oli Pariisiin saapunut maalainen, kuten moni hänen elokuviensa ja uuden aallon elokuvien roolihahmoista. Maalainen kaupungissa -teema toistuu hänen elokuvissaan (samoin kuin Honoré de Balzacin romaaneissa) ja ilmenee kohtauksissa, joissa liikutaan, siirrytään toisaalle... Rivette saapui Pariisiin vuonna 1949, tapaamiseen Saint-Sulpicen aukiolla sijaitsevaan kirjakauppaan. Siellä hän kohtasi Jean Gruault'n (käsikirjoittajan, joka työskenteli kyseisessä kirjakaupassa!)... ja vain muutamassa viikossa hän oli luonut siteet "perheeseensä" (Rohmer, Truffaut, Godard...). Tästä joukosta sukeutui todellinen cinéfiilien klaani, salaliittolaisten ryhmittymä, jonka varaan ranskalainen uuden aallon elokuva myöhemmin rakentui ja jota Rohmer ei epäröinyt verrata Balzacin kertomusten "Kolmentoista" salaseuraan. Tulevista elokuvaohjaajista monet saavuttivat ensimmäiset kannuksensa elokuvakriitikoina erityisesti Cahiers du Cinéma -lehdessä (siinä kuuluisassa keltakantisessa julkaisussa, jonka André Bazin, Jacques Doniol-Valcroze, Leonide Keigel ja Lo Duca perustivat vuonna 1951). Rivette toimi lehden päätoimittajana vuodesta 1963 vuoteen 1965.

- •

Vaikka Cahiers du Cinéman toimituskunta piti häntä oppi-isänään, yksinäisyyteen taipuvainen, varautunut, pimeissä elokuvateattereissa viihtynyt ja maanalaista kulkuvälineenä suosinut Rivette oli kriitikkojoukosta ja kuuluisista elokuvaohjaajista vähiten huomiota herättävä. Kyse ei ollut vain luonteenpiirteestä vaan suhtautumisesta maailmaan, mikä vaikutti myös hänen käsitykseensä taiteen tekemisestä. Rivette vältti keskipisteessä olemista eikä halunnut kuulua mihinkään. Hänen tapanaan 
oli vetäytyä syrjään ja asettua marginaaliin, ja hän pyrki välttämään ennalta määriteltyä. Rivetten elokuvat eivät noudata lajityyppejä. Ne eivät ole poliisielokuvia, scifi-elokuvia, romanttisia komedioita tai seikkailuelokuvia... mutta samalla ne ovat kaikkia näitä ja vielä enemmänkin elokuvien kaikilla tasoilla vallitsevan rajattoman mielikuvituksen ansiosta: juonensa purkavista käsikirjoituksista näyttelijöiden improvisoituihin eleisiin, epätodennäköisistä tilanteista maailman sisällään pitämään odottamattomaan komiikkaan, mikään ei jäykisty ennalta määritellyksi genreksi.

Rivetteläisen taiteen tekemisen olemuksen määrittelyssä käsite work in progress on hyvä apuväline. Se jättää tilaa näkyvän ja piilotetun väliselle suhteelle, toisin sanoen antaa mahdollisuuden suhtautua käänteisesti siihen, mitä elokuvassa ei näytetä tai jopa pyritään kätkemään. Rivette tekeekin elokuvan ennakkovalmistelusta teoksen näkyvän sydämen. Ulkoreuna muodostaa keskuksen. Käsite nostaa näkyviin ohjauksen keinot (kokeilun, toiston ja improvisaation). Voidaan siis puhua elokuvallisen kokeilemisen elokuvasta sanan varsinaisessa merkityksessä (klassisessa elokuvassa kokeilu jää yleensä kuvan rajauksen ulkopuolelle). Ohjaajana Rivette asettuu takaalalle, väijyy sepitteen voimia (puissances $d u$ faux $)^{1}$ ja toimintaa; odottaa, että pintaan nousee se, mitä hän etsii, ja vangitsee sitten mielikuvituksen todellisuuden, joka ei tarkoita samaa kuin uskottavuudelle perustuvan fiktioelokuvan sovinnainen realismi. Rivetten luovuus kumpuaa tästä prosessista... samoin kuin hänen elokuviensa sisältämä mysteeri.

Rivetten luovasta elokuvakritiikistä nousee esiin kaksi keskeistä käsitettä. Paitsi että ne määrittävät hänen näkemystään elokuvakritiikistä, ne ovat yhtä lailla elokuvan tekemiseen sopivia elokuvallisia ideoita (ja erityisen osuvia puhuttaessa elokuvasta Out1). Nämä käsitteet ovat ohjaus tai näyttämöllepano (mise en scène) ${ }^{2}$ ja moderni (modernité).

Käsite näyttämöllepano oli perusta Cahiers du Cinéma -lehden toimittajien elokuvakritiikeissään rakentamalle teorialle. Tällä käsitteellä Rivette ei viitannut sisältöön (elokuvan käsittelemään aiheeseen) vaan johonkin, joka on olennaista elokuvalle ja joka osoittaa, että elokuvan taustalla on omaääninen tekijä (auteur). Termi auteur on toinen keskeinen ilmaisu Cahiers du Cinéma -lehden kritiikin sanastossa ja sisältyy ajatukseen "tekijänpolitiikasta" (la politique des auteurs, suomessa puhutaan yleensä "auteur-teoriasta"): tavoitteena oli ennen kaikkea tiettyjen väheksyttyjen klassisten amerikkalaisohjaajien maineen palautus teorian avulla. En käsittele tässä yhteydessä termiä tekijyys, sillä Rivette ei hyödynnä sitä omissa elokuvissaan; riittäköön, että toteamme, että tekijyys voidaan johtaa näyttämöllepanosta, eikä toisin päin.

\footnotetext{
1 Käsitteen suom. ks. Hongisto 2013, 37-41, <https://www.netn.fi/sites/www.netn.fi/files/netn-132. pdf>.

2 Termi mise en scène voidaan kääntää kahdella tavalla: ohjaus tai näyttämöllepano. Käytämme jatkossa suomennosta näyttämöllepano. Miksi näyttämöllepano eikä ohjaus? Suomen kielessä ohjaus toki pitkälti vastaa sitä, miten termiä mise en scène käytetään. Näyttämöllepano kuitenkin säilyttää paitsi a) termin yhteyden teatteriin myös b) ajatuksen tietyntyyppisestä tekemisen prosessista (ohjaaminen on näyttämöllä nähtävien elementtien asettelua merkityksiä luovalla tavalla). Termin lanseerasi teatteriohjaaja (ja sittemmin myös elokuvaohjaaja) André Antoine 1800-luvun lopulla - ajatuksena se, että teatterinäyttämön järjestäminen ei ole vain tekninen prosessi, vaan kyse on merkityksen rakentamisesta. Elokuvan kohdalla kyse on ollut myös termin uudelleen ajattelemisesta: mikä elokuvassa on "näyttämö" ja miten sen "asettelu" tapahtuu?
} 

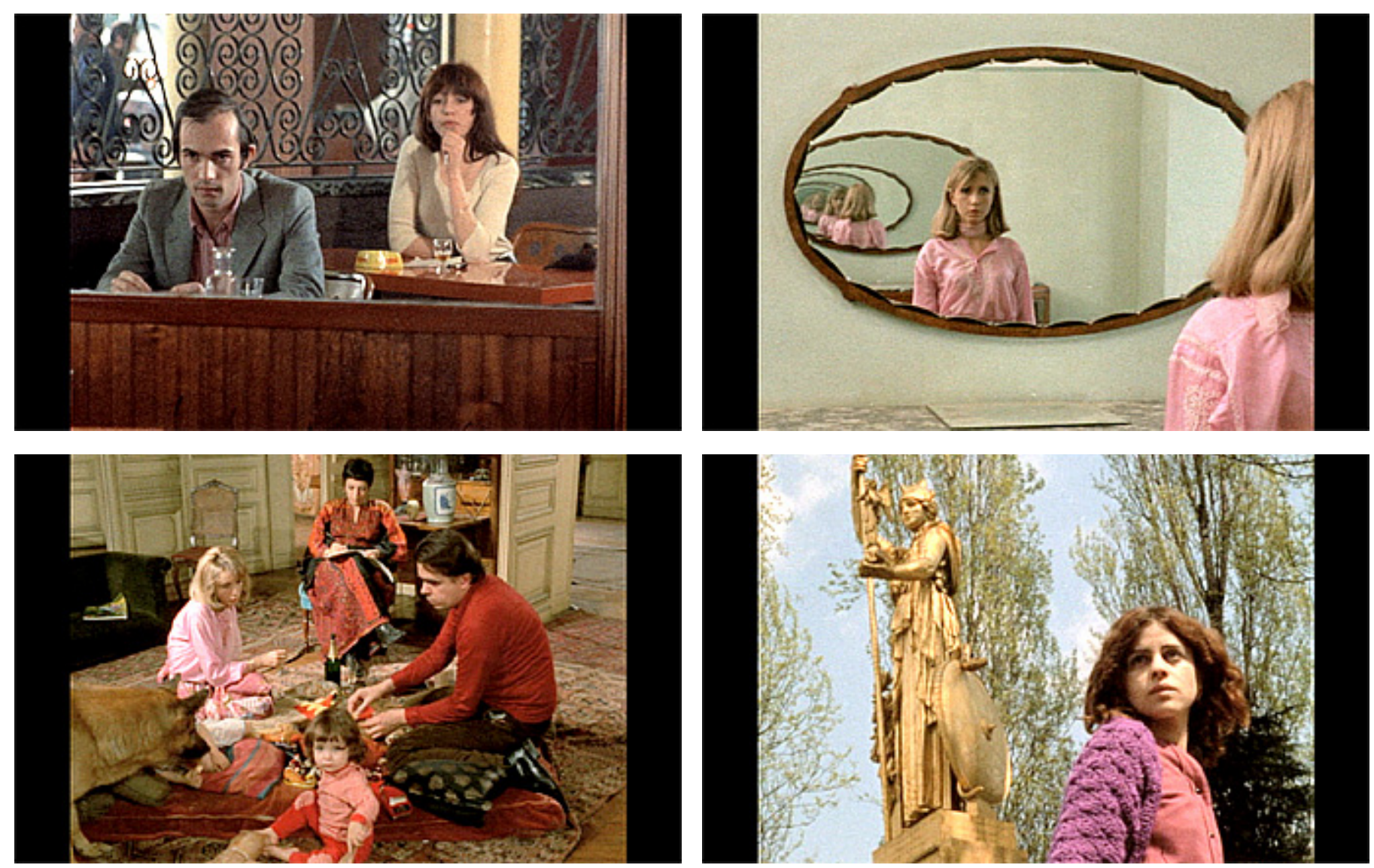

Näyttämöllepano (mise en scène) on keskeistä Rivetten elokuvissa, kuten Out1. Kuvat: kuvakaappauksia elokuvasta Out1.

Kriitikon uransa aikana Rivette muutti ja täydensi useaan kertaan käsitystään termistä näyttämöllepano, jonka hän liitti ajatukseen jostakin erityisesti elokuvalle ominaisesta. Termi näyttää juontavan juurensa yhtäältä teatteriin, joka taidemuotona kiinnosti Rivetteä, koska sen myötä oli mahdollista tehdä ero elokuvaan - erityisesti teatteria ja elokuvaa yhdistävän ja toisiinsa lähentävän näyttelijäntyön ansiosta. Toisaalta termi jättää tilaa kirjalliselle perinnölle ennen kaikkea viittaamalla tekstiin, joka on "pantava näyttämölle" teatteriesitystä varten. Tästä huolimatta Rivette ei lakannut koskaan esittämästä, että näyttämöllepano on se "moderni" paikka, jossa ajatus muuttuu muodoksi. Näyttämöllepano on elokuvalle kuuluvan arvoituksen paikka, jossa ajatus ilmentyy jollakin toisella tavalla. Tästä johtuen elokuvan ja muiden taiteiden välille on rakennettava hienovaraisia eroja (ohi viittausten tai näkyvien lähteiden) mutta myös otettava huomioon modernin ajattelun mahdollisuus, joka rakentuu muiden taiteiden kanssa vuorovaikutuksessa olevan elokuvan muodon modernismille (ohi adaptaation tematiikan). Yleisellä tasolla ajattelun moderni esittäminen (mise en scène) lainaa elokuvallisilta muodoilta.

Tästä juontuu toinen suuri käsite moderni elokuva. Moderni elokuva ei tarkoita samaa kuin avantgarde-elokuva, kokeellinen elokuva tai underground-elokuva, joihin Cahiers du cinéma suhtautui hyvin epäluuloisesti. Toimituksen sisällä Rivette oli modernin ilmaisun keskeinen ajattelija ja se, joka pohdinnoissaan useimmin viit- 
tasi käsitteeseen. Laajasti sivistyneenä hänellä oli mielessään kaikkein syvin ajatus modernista linkitettynä siihen, mitä aiemmin oli tehty ja tehtiin hänen aikanaan eri taiteen aloilla - kirjallisuudessa, teatterissa, kuvataiteissa ja musiikissa. Todetessaan, että moderni on "vastavuoroisen tiedon ilmiö", hän uskoi ilmaisun muotojen tai ajatusten muotojen dynaamiseen yhteisöön. Niinpä Cahiers du Cinéman toimituksessa nousi esiin kysymys elokuva-alan ulkopuolisten ajattelijoiden, kuten Levi-Straussin, Boulezin tai Barthesin, kutsumisesta mukaan kirjoittajiin. ${ }^{3}$ André Labarthen mukaan "Rivette ajatteli modernia ilmaisua yhtä aikaa klassiselle kulttuurille vastakkaisena ja uusiin taiteellisiin muotoihin yhteen sulautuneena". Labarthe muistuttaa, että "aikaa luonnehti uuden romaanin (le nouveau roman) ja Tel Quel -lehden ympärille rakentunut kirjallinen liike sekä samanaikainen humanististen tieteiden kehitys... Labarthe toteaa lopuksi: "Kaikki liikehti samassa rytmissä". Rivette oli todennäköisesti kiinnostuneempi ajankohdan musiikista, hän kävi Boulezin konserteissa ja myönsi avoimesti musiikillisten vaikutteiden roolin elokuvissaan (hän puhuu Bartokin vaikutuksesta elokuvaan Pariisi kuuluu meille ja Stockhausenin "sekoituksesta rakennettua ja sattumanvaraista"). Rivette tavoitteli atonaalista elokuvaa... Tämä korostaa hänen elokuvallisen hankkeensa eroa muihin elokuvan tekemisen tapoihin. Seuraava André Labarthen pohdinta sopii itse asiassa erityisesti Rivetteen: "[U]usi aalto ei lopultakaan ole kuvailemamme liike vaan joukko poikkeuksia. Ja nämä poikkeukset puhuvat modernin ilmaisun kieltä, kuten teosten kaupalliset epäonnistumiset osoittavat!"4

\section{$\bullet \bullet$}

Rivetteläisen näkemyksen mukaan kriitikon työ resonoi siis elokuvaohjaajan luovan työn kanssa (Godard on todennut yksiselitteisesti: "Meille kritiikkien kirjoittaminen oli jo elokuvien ohjaamista"). Pyrkimyksenä on tavoittaa "oleellinen" (Rivetten Otto Premingerin elokuvaa Enkelin kasvot käsittelevän artikkelin otsikko vuodelta 1954). Sama pätee sekä kritiikkiin että elokuvan tekemiseen. Tästä taas juontuu ajatus näyttämöllepanon merkityksen korottamisesta, sillä juuri näyttämöllepano tuottaa elokuvan idean, toisin sanoen sen muoto-idean, elokuvallisen idean tai kuva-idean, "joka on lähtökohtaisesti ajatus tietynlaisesta elokuvasta".

Rivette toteaakin, että näyttämöllepano on vastakohta käsikirjoitukselle, että merkityksellistä ei ole käsikirjoitus vaan "salaisen muodon, kaiken taiteen päämäärän" tavoittaminen (Nicholas Raytä käsittelevä artikkeli "Uuden luomisesta" [De l'invention] vuodelta 1953). Lisäksi Rivetten elokuvissa yhdistelmä näyttelijä-roolihahmo eroaa teatterinäyttelijästä, koska näyttelijän ja roolihahmon välinen suhde ei rakennu en-

\footnotetext{
${ }^{3}$ Rivetten ja Michel Delaha........................ johdanto Barthesin kanssa käymäänsä keskusteluun on eksplisiittinen: "Avaamme sarjan keskusteluja joidenkin nykykulttuurin keskeisten todistajien kanssa. Elokuvasta on tullut samanarvoinen osa kulttuuria kuin kaikista muistakin kulttuurin osa-alueista. Kaikkien taiteiden, kaiken ajattelun on viitattava elokuvaan, kuten elokuvan tulee viitata niihin. Se on tämä välillä ilmeinen (ei välttämättä paras ilmentymä), välillä hajanaisen vastavuoroisen informaation ilmiö, jota haluaisimme muun muassa näiden keskustelujen kautta käsitellä. Alati läsnä oleva elokuva, milloin taka-alalla, milloin etualalla, sijoitetaan laajempaan perspektiiviin, jonka arkistoille tai idolatrialle rakentuvat näkökulmat (joilla myös on paikkansa) uhkaavat saada meidät unohtamaan." Cahiers du Cinéma n¹47, syyskuu 1963, 21.

${ }^{4}$ Antoine de Baecquen ja Charles Tessonin keskustelu André Labarthen kanssa (7.12.1998). "Comment peut-on être moderne?" (Miten voi olla moderni?) La Nouvelle Vague, Petite Bibliothèque des Cahiers du Cinéma (1999).
} 
nalta kirjoitetussa vaan kuvauksissa syntyvässä fiktiossa. Tämä depersonalisaation oppitunti kohdistuu myös katsojaan, kun Rivette toteaa, että "emootio ei ole taiteen perimmäinen tarkoitus" (Hitchcockin elokuvaa Minä tunnustan käsittelevä artikkeli). Hän erottaa näin todellisen elokuvan näyttämötaiteiden odotuksista ja pakenee identifikaatiota, joka on ominaista kaikille representaatioon nojaaville taiteille. Samoin hän pyrkii osoittamaan (elokuvassa La Belle Noiseuse - tuntematon mestariteos), että taidemaalarin malli on elokuvaohjaajan ei-malli...

Tehdessään näin Rivette nostaa esiin toisen vahvan eron, hän asettaa vastakkain "Ohjaajan" (metteur en scène) ja tavallisen "ohjaajan" (réalisateur). Kuten termin réalisateur kantasana (réel, tosi) osoittaa, jälkimmäinen pyrkii rakentamaan vaikutelman todellisuudesta, hakee toden tuntua, kun taas ensimmäinen etsii muotoa, joka tuottaa totuuden luomalla elokuvan salaisen muodon (joka myös elokuvakritiikin on löydettävä etääntymällä juonesta ja näkyvistä tapahtumista).

\section{Merkityksiä odotuksen tilassa tai elokuvan työ teoksessa $\mathrm{Out1}$}

Out1: Noli me tangere (1970-71) perustuu väljästi Honoré de Balzacin kirjoittamaan romaaniin Histoire des Treize. Elokuva on kuuluisa pitkästä kestostaan (12 tuntia 40 minuuttia), jonka takia teosta ei ole alkujaan esitetty elokuvateattereissa, mutta sitä ei myöskään hyväksytty osaksi television tarjontaa. Vuosina 1971-72 elokuvasta leikattiin neljä tuntia ja 20 minuuttia kestänyt lyhytversio, joka sai ensi-iltansa vuonna 1974 nimellä Out1: Spectre.

Out1: Noli me tangeren ensimmäinen julkinen esitys (työkopio) järjestettiin Le Havressa syyskuussa 1971 (Maison de la Culture du Havre). Teos koostuu kahdeksasta episodista, jotka muodostavat spiraalimaisen sarjan:

1. Lililtä Thomasille

2. Thomasilta Frédériquelle

3. Frédériquelta Sarahille

4. Sarahilta Colinille

5. Colinilta Paulinelle

6. Paulinelta Emilielle

7. Emilieltä Lucielle

8. Lucielta Marielle

Elokuvan nimi Out1 juontaa juurensa varhaisempaan toteutumatta jääneeseen hankkeeseen. Kyseistä hanketta, joka sai nopeasti nimekseen Out, Rivette kutsui nimellä Out zéro (viitaten lehtien julkaisutoimintaan liittyvään tapaan, jossa koenumerona toimivaa luonnosta kutsutaan "nollaversioksi"). Toteutumaton teos todellakin muodostaa aiheensa tasolla luonnostelman vuoden 1971 elokuvasta. Tämän vahvistavat osaltaan seuraavat Rivetten sanat: "Elokuvan L'Amour fou (1969) jälkeen ajattelin tehdä elokuvan noin kymmenestä nuoresta jossakin maakuntayli- 


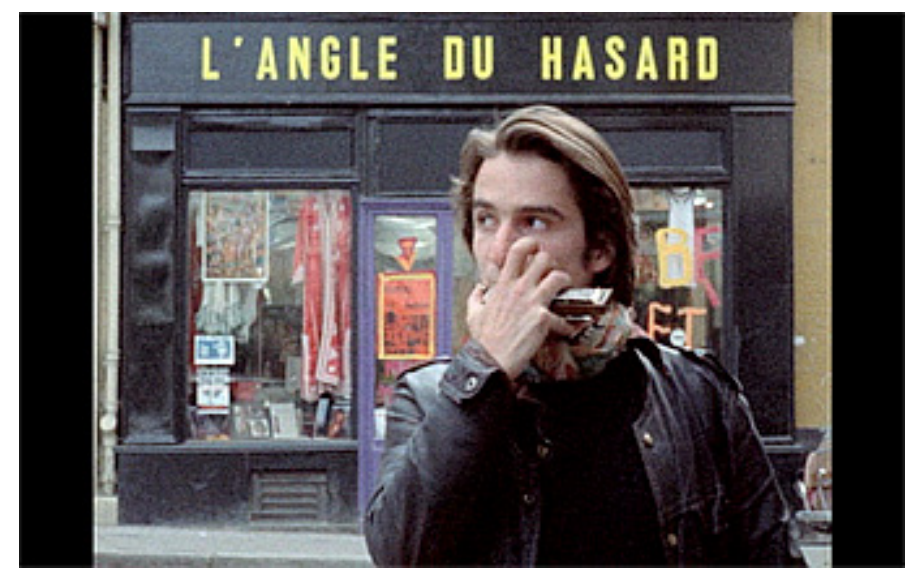

Out1 juontaa juurensa varhaisempaan toteutumatta jääneeseen hankkeeseen Out zéro. Kuva: kuvakaappaus elokuvasta.

opistokaupungissa, kuten Aix en Provence. Tarkoitus oli seurata tätä ryhmää kolme tai neljä vuotta: teoreettisesti seurue on pysynyt samana, mutta todellisuudessa sen kaikki alkuperäiset jäsenet ovat kadonneet, kohtaamispaikat ovat vaihtuneet, arjen rituaalit ja kielen koodit ovat muuttuneet. Kaiken taustalla on hyvin tšehovilainen johtolanka... Kyseinen hanke oli olemassa ainoastaan päässäni, en kirjoittanut siitä sanaakaan, mutta tarkka nimi Out löytyi nopeasti." ${ }^{5}$

Rivetten huomio antaa ymmärtää (kuten sanan puhekielinen käyttö osana ranskan kieltä), että ollessaan "out", on ulkopuolella, syrjässä, marginaalissa, aivan kuten ryhmän nuoret ja heidän elämänsä ovat sivussa yhteiskunnasta. Termi liittyy myös kuluvaan aikaan, koska kaikki muuttuu, muuntuu joksikin, joka on ollut - has been - ilmaisu, jota myös ranskan puhekielessä käytetään niistä, jotka eivät enää ole mukana menossa, jotka ovat epämuodikkaita aikansa eläneine tapoineen. Elokuvan nimi nostaa esiin kysymyksen heidän hankkeensa merkityksestä, onko sillä ylipäätään merkitystä, jos se on jo vanhentunut? Mitä merkitsee heidän yhteisönsä henki, heidän seurueensa? Ensimmäisenä on ajatus jäämisestä ajan tai leikin ulkopuolelle (elokuvan intohimoisia harrastajia tai Cahiers du Cinéman toimituskuntaa ei pidä todennäköisesti erottaa tästä kysymyksestä).

Päästäksemme käsiksi elokuvan analyysiin on hyvä pitää mielessä eräs Rivetten elokuvailmaisun olennaista luonnetta kuvaava lausahdus. Se kuullaan heti hänen ensimmäisessä elokuvassaan Pariisi kuuluu meille: "Kaikki on hieman irtonaista, mutta luettavissa / yhteen liitettävissä toisella tasolla." Toteamuksen lausuu elokuvassa esiintyvä teatteriohjaaja, ja se tuottaa hienovaraisen sanaleikin, joka perustuu ranskan kielessä verbien lire (lukea) ja lier (liittää yhteen) yksikön kolmannen persoonan homonymiaan (sanat lit ja lie lausutaan täsmälleen samalla tavalla). Fraasi antaa ymmärtää, että oleellinen ei aina välity kaikkein näkyvimmän kautta (lukea), että on sijoituttava usealle tasolle yhtä aikaa (liittää yhteen).

\footnotetext{
5 "Trois films fantômes de Jacques Rivette" (Jacques Rivetten kolme haamuelokuvaa). Cahiers du cinéma/Fiction (2002), 8-9.
} 
Rivette on aina pitänyt sanoilla leikittelystä, ja sanaleikkeihin onkin syytä kiinnittää huomiota, sillä kyseinen tapa ajatella saattaa johtaa Rivetten ilmaisemaan sen, mitä hän kutsuu elokuvan ideaksi ja jonka hän toteuttaa muotoon liittyvien osa-alueiden kokoonpanona. Elokuvastaan Pariisi kuuluu meille Rivette esimerkiksi sanoo, että "tukeutumalla dekkarielokuvan juonirakenteeseen hän yritti kertoa tarinan ideasta" (tutkinnan kohteena on idea, joka linkittyy tarinaan samoin kuin rikos poliisin tekemään selvitystyöhön). Elokuvastaan L'Amour fou hän kertoo, että olisi voinut tehdä "teoksen, joka perustuu puhtaasti kalenterin kuljetukseen, mutta että hän halusi myös tehdä tarinan, joka on ympyrän muotoinen". Elokuvastaan Nunna Rivette lausuu, että "lähtöidea oli sanaleikki, useasta erillisestä osasta koostuva, rakenteeltaan kennomainen (cellulaire) elokuva, koska nunnatkin elävät omissa erillisissä kammioissaan (cellule)".

Kuten homonymia verbien lukea ja liittää yhteen välillä osoittaa, Rivetten elokuvien kaksinkertainen tulkinta on välttämätön. Ryhmien näennäisen järjestäytymisen kautta, toisin sanoen antamalla katteettomia todisteita teeman olemassaolosta, ohjaaja kuljettaa elokuviinsa ajatuksen salaisuudesta, salaliitosta, kätketystä. Elokuvan idea ei ole aihe, temaattinen sisältö, vaan materiaalin yhteen punoutuminen sen kiinnittyessä ja liittyessä elokuvan muotoon. Eräänlainen käänteentekevä muutos mainitaankin elokuvan Pariisi kuuluu meille lopussa: "organisaatio on idea, sitä ei ole koskaan ollut olemassa muutoin kuin mielikuvituksessa". Näin katoaa dekkarielokuvan juoni, jonka tehtävänä oli vain punoa yhteen idean langat, tuottaa paikka ääneen sanomattomalle salaisuudelle, josta emme tule tietämään mitään.

\section{$\bullet \bullet$}

Idea on muoto-idea (idée-forme), jonka merkitys Rivetten elokuvissa jää aina odotuksen tilaan erityisesti merkitsijän (signifiant) väkevyyden ansiosta. Roland Barthesin kanssa käymässään keskustelussa hän toteaa: "Se mikä tuottaa merkitsijän väkevyyden ei ole merkitsijän selkeys vaan se, että se nähdään merkitsijänä - merkityksestä [sens] riippumatta." Merkitsijän väkevyys saa mielikuvan merkityksestä heräämään, se synnyttää halun määrittää merkitys, mutta tämä merkitys on täysin kiinnittynyt muotoon, joka on odotuksen tilassa. Oleellista on merkityksen herääminen (ei tietyn merkityksen tuottaminen). Ennalta määritetyn merkityksen poissaolo, merkitys odotuksen tilassa, tuottaa teoksen, joka on plastilliselta muodoltaan kysymys. (Vertauksena: Hämähäkinverkko piilottaa yhtä lailla tekijänsä - joka on vetäytynyt budoaariinsa - kuin rakennelman käyttötarkoituksen; jäljelle jää muoto...)

Tästä voimme päätellä, että teoksen nimi Out on julkilausuma, jonka perusteella totuttu merkitys jätetään syrjään, kaikki yksiselitteinen tematiikka hylätään. Toisin sanoen teos nähdään kysymyksenä odotuksen tilassa, joka jää jokaisen itse ja yksin käsitteellistettäväksi.

Jos palataan takaisin elokuvaan ja sen useat eri osa-alueet yhteen liittävään luonteeseen, huomio kiinnittyy sarjaan episodeja, jotka nimeävät useita roolihahmoja. Roolihahmoista rakentuu kaksi harrastajanäyttelijäseuruetta: yhtä johtaa näyttelijä 

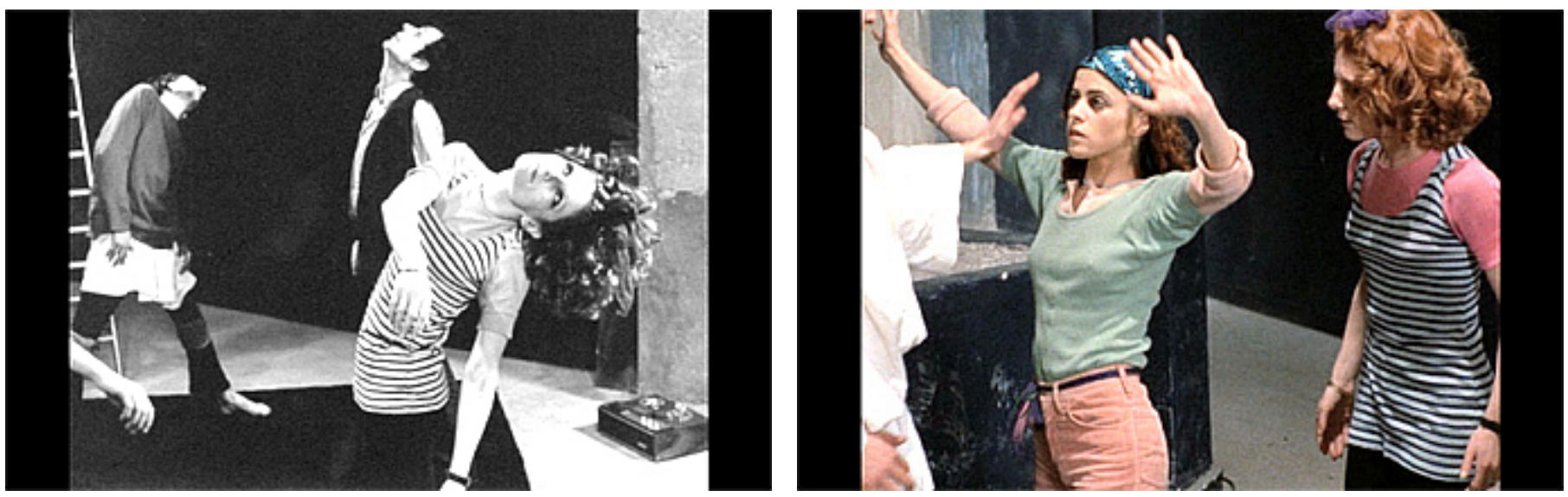

Out1:n katsoja on mukana lukuisissa pitkissä harjoituksissa, joissa lämmitellään, työstetään hengitystä, huudetaan, elehditään summittaisesti ja ryömitään. Kuvat: kuvakaappauksia elokuvasta.

Michèle Moretti (Lili), toista näyttelijä Michael Lonsdale (Thomas). Katsoja on mukana lukuisissa pitkissä harjoituksissa, joissa lämmitellään, työstetään hengitystä, huudetaan, elehditään summittaisesti, ryömitään... siitä huolimatta, että kummallakin ryhmällä on käytössään teksti, he pitävät kädessään kirjaa. Vielä ei olla vaiheessa, jossa puhutaan, lausutaan tai ilmaistaan tekstiä näyttelijän tulkinnan kautta...

Muiden roolihahmojen joukosta erottuu edelleen kaksi hahmoa: näyttelijä JeanPierre Léaud (häntä tullaan kutsumaan etunimellä Colin), joka näyttelee kuuromykkää ja joka kerjää pariisilaiskahviloiden terasseilla. Henkilögalleriasta erottuu myös Juliet Berto (Frédérique) enemmän tai vähemmän kokeneen varkaan roolissa sekä muita näyttelijöitä, kuten Bulle Ogier ja Bernadette Lafont, joiden roolia ei ole helppoa tunnistaa.

Tästä voi päätellä, että kerronnan konventioita ei kunnioiteta. Ennemmin kuin kertomukseen (jossa Aristoteleen oppien mukaisesti on alku, keskikohta ja loppu), katsoja upotetaan valmistelematta roolihahmojen ja ajankohtaan liittyvien asioiden virtaan. On odotettava pitkään, ennen kuin on mahdollista nimetä tai määritellä rooleja tahi muodostaa niiden välisiä suhteita. Teot ja niiden takana olevat syyt jäävät usein hämäriksi, samaan aikaan, kun katsoja pohtii herkeämättä mielessään erään
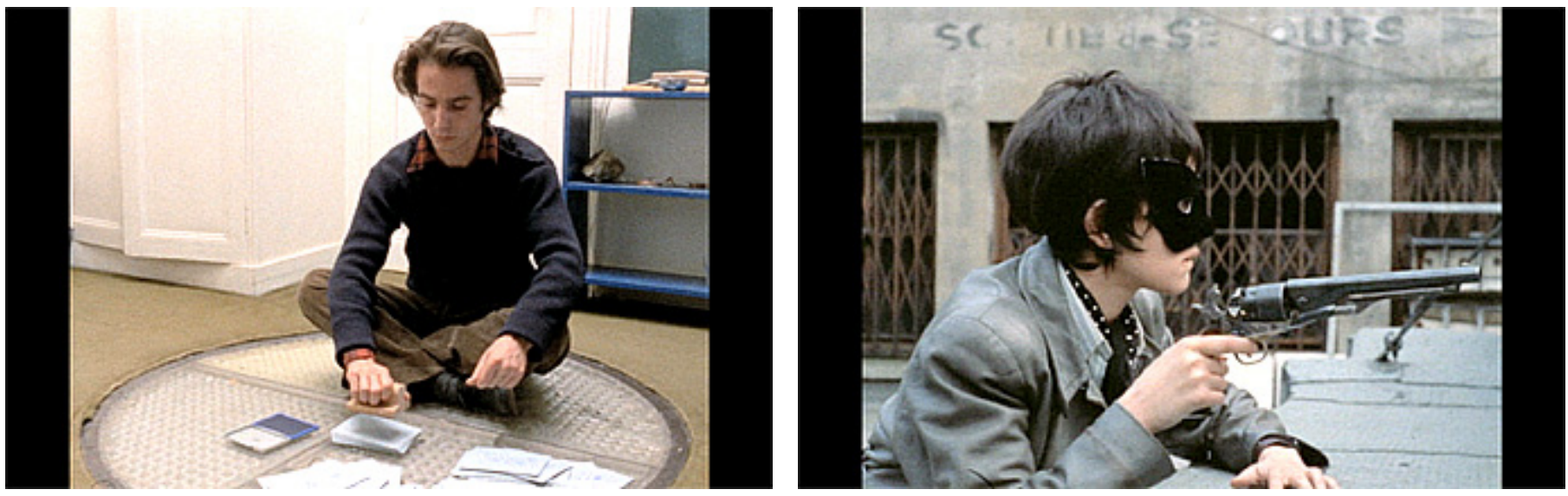

Out1:n roolihahmojen joukosta erottuu kaksi hahmoa: näyttelijä Jean-Pierre Léaud (Colin) ja Juliet Berto (Frédérique) varkaan roolissa. Kuvat: kuvakaappauksia elokuvasta. 
Igorin ja erään Pierren, jotka eivät esiinny missään vaiheessa elokuvaa, kohtaloa. Yhdistettynä johonkin epämääräisesti poliittiseen arvoitus, mysteeri ja salaisuus kelluvat ilmapiirissä, johon liittyvät kollektiivit, ryhmät, yhdistykset, lahkot. (Tämä osallistumisen sattumanvaraisuus luonnehtii myös Balzacin Kolmentoista ryhmää [le groupe des Treize].) Kun vastassa ovat kaikki edellä mainitut semanttiset hämäryydet, teoksen muoto nousee esiin: roolihahmojen piirileikki, itse kunkin ilmestymiset ja katoamiset, heidän epäjohdonmukaiset kulkunsa kaduilla, havainto Pariisin rikkonaisesta kartastosta erilaisine itsessään epäyhtenäisine ihmisryhmineen (hipit, Madagascarin eurooppalaiset, lehteä perustava poliittinen ryhmittymä, varkaat, shakinpelaajat...)

\section{$\bullet \bullet \bullet$}

Edellä kuvattua muotoa koskeva kriittinen työskentely johdattaa pohdiskelemaan uudestaan merkitsijän väkevyyttä sellaisenaan. Merkitsijä ei kuitenkaan välttämättä saa tarkkaa merkitystä vaan tuottaa kysymyksiä vastausten sijaan.

Tämä pitää sisällään useita näkökohtia. Esittämisen tasolla Rivette on ja pysyy Pariisin kuvaajana (ohi sen tosiasian, että taloudellisista syistä johtuen uuden aallon nuoret ohjaajat päätyivät työskentelemään pääkaupungin alueella). Mutta Rivetten Pariisi on hyvin erilainen kuin uuden aallon Pariisi. Se on salaperäisempi ja samaan aikaan täysin realistinen. Toisin kuin muiden uuden aallon ohjaajien töissä (Truffaut, Godard, Rohmer, Chabrol), jotka tunnetaan "muotokuvina 1960-luvun nuorisosta" - ajatellaan vaikka Godardin elokuvaa Viimeiseen hengenvetoon, Truffaut'n 400 kepposta, Rohmerin Leijonan merkkiä tai Vardan elokuvaa Cléo - viidestä seitsemään (jotka tarjoavat omaan aikaansa kiinnittyville roolihahmoille ja tilanteille ajanmukaisen ympäristön), Rivetten elokuvissa kuva yhteiskunnasta on toinen. Hänen Pariisinsa kiinnittyy aikaan, joka on läpinäkymättömämpi, monimutkaisempi. Se ei johdu siitä, että Rivette tekisi elokuvia historiallisesta menneisyydestä, pukuelokuvia (Nunnaa lukuun ottamatta) tai futuristisia elokuvia. Tästä ei ole kysymys.

Hänen näyttämänsä kuvat ovat ehdottoman ajankohtaisia, autenttisia, lavasteita ei ole ehostettu. Tämä todellakin on Pariisi omana itsenään, sellaisena, kuin se on kuvaushetkellä ollut, mutta kuvat kaupungista myötäilevät tietyn esteettisen valinnan mukanaan tuomia reunaehtoja.

Rivetten tavoittelema kuva Pariisista on ensinnäkin makukysymys, se liittyy tiettyyn traditioon, jonka voi tunnistaa nousevaksi Balzacin pariisilaistarinoista. Toiseksi, kuva kumpuaa myös kansan rakastamista kertomuksista, 1800-luvun ja 1900-luvun alun melodraamoista, sekä elokuvan varhaisvuosien kuvastosta, mykkäelokuvasta, Fantômas-sarjalle ominaisista puoliksi vakavista, puoliksi leikkisistä fantasioista... sävy, jota Jean-Pierre Léaud'n ja Juliet Berton liioiteltu näytteleminen hyvin ilmentävät.

Kyseessä on Pierre Souvestren ja Marcel Allainin luomien melodraamojen ja rikoselokuvien Pariisi. Souvestre ja Allain loivat Fantômas-hahmon, jonka ympärille Louis Feuillade teki viisi elokuvaa vuosina 1913-1914, juuri ennen ensimmäistä maailmansotaa. Tälle mykkäelokuvan ja sarjaelokuvien perinteelle ja populaarikirjallisuudelle Rivette osoittaa kunnioitustaan käyttämällä esimerkiksi omalle ajalleen epätyypillisiä planssitekstejä (elokuvassa Céline et Julie veneilevät planssitekstit on laadittu Art Nouveau -henkisellä typografialla). Tämä antaa valituille luonnollisille lokaatioille odottamattoman, selittämättömän leiman. Elokuva Out1 alkaa planssitekstillä, joka määrittää ajan ja paikan, kun taas teos kokonaisuudessaan on jaettu episodeihin, joiden otsikot rakentavat sarjamaisen etunimien piirileikin. Ja vaikka 


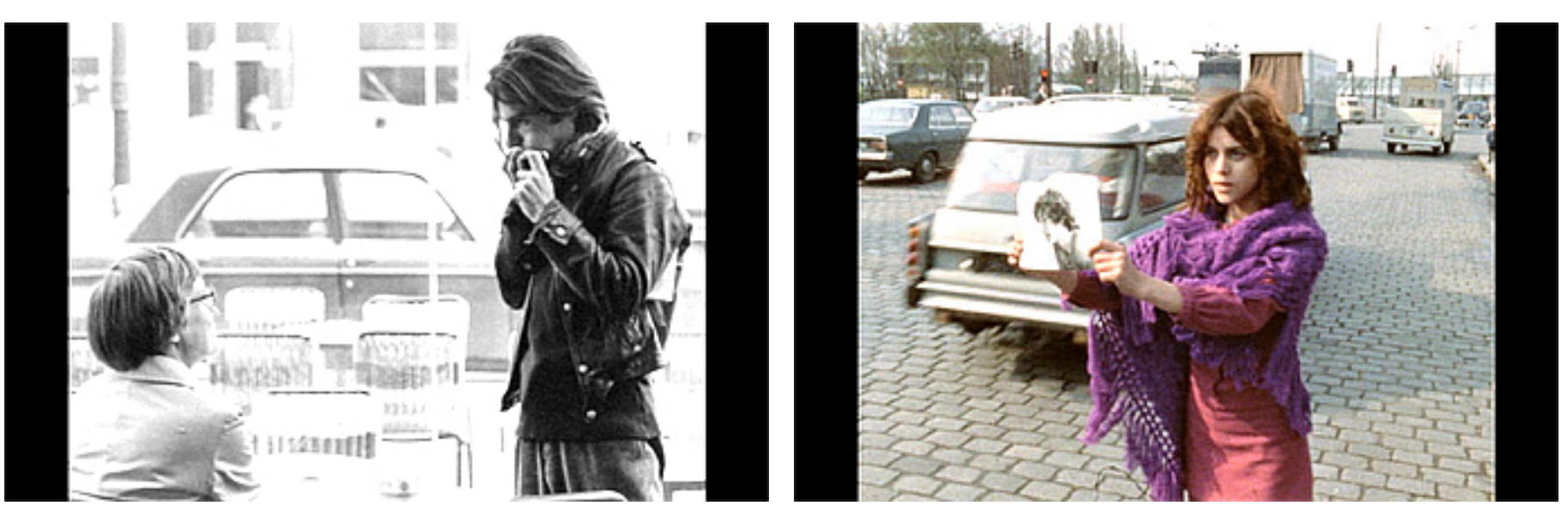

Rivetten Pariisi on salaperäinen ja samaan aikaan täysin realistinen. Kuvat: kuvakaappauksia elokuvasta.

"jatkuu"-maininta jääkin puuttumaan elokuvasta, on selvää, että teoksen kesto voisi ylittää nykyiset 12 tuntia ja 40 minuuttia.

Muissa elokuvissa (erityisesti elokuvassa Céline ja Julie veneilevät) viittaus mykkäelokuvaan on puoliksi vakava, puoliksi leikkisä... Emmehän unohda, että Gilles Deleuzelle Céline ja Julie on yksi ranskalaisen elokuvakomedian suurimmista teoksista. Mikään ei kiellä meitä näkemästä elokuvassa Out1 jälkeä mykkäkomedialle ominaisesta slapstickistä, jos ajatellaan kehollista liioittelua, pantomiimia, Frédériquen (Juliet Berto) tai Colinin (Jean-Pierre Léaud) epäuskottavuutta. Hupaisat hetket, jotka paljastavat tiettyyn muotiin, epookkiin tai pariisilaisuuteen sisältyvän parodian, nostavat toisaalta esiin satiirin suonen.

Tyytymättä ainoastaan viittaamaan käyttäytymiseen, joka oli muodissa mainitsemamme mykkäelokuvakauden aikana tai Balzacin tuotannossa, Rivetten estetiikka on kunnianhimoisempaa sen suhteessa ajalliseen moninkertaistumiseen. Elokuva tavoittelee mahdollisen imeytymistä nykyiseen: ohjaaja etsii kohtaa, jossa todellista ja mahdollista on mahdotonta erottaa toisistaan. Hänen lähestymistapansa on hyvin avoin, mielikuvituksellinen, epätodennäköinen, sillä todennäköinen rakentuu realismille, ja realismi taas on vastakkainen vielä tuntemattoman mahdollisen määrittelemättömyyden kanssa. Vuoden 1968 vallankumouksellisuus pyrki muuttamaan toden rajattomiksi mahdollisuuksiksi, kuten eräs toukokuun kuuluisa iskulause ilmaisee: "katukivien alla ranta" (Sous les pavés, la plage).

Eikö olekin niin, että elokuvan Out1 pitkät otot antavat mahdollisuuden odotuttamiseen: mitä pitkästä kehittelystä seuraa, mitä on odotettavissa, mitä jatkossa tapahtuu tai mitä kaaos, huudot ja eleet tuovat tullessaan? Samaan aikaan tapahtumien toistot ja uusinnat, päällekkäisyydet tai polveilut osallistuvat ennalta määrättyyn suuntaan kulkevan, klassiseen ja tarkoin määriteltyyn loppuratkaisuun pyrkivän hallitun tarinankerronnan tuhoamiseen.

Kopioimatta mykän sarjaelokuvan maailmaa, Jacques Rivette pyrki löytämään tuon maailman runollisuuden läpi filmografiansa kokeillen erilaisia tulokulmia, turvautumalla aikalaiskuvien, -tapahtumien, -roolihahmojen tai -paikkojen sitkeään merkitsevyyteen, josta välittyy tunne jostakin yllättävästä, kaksitahoisesta 
tai monimerkityksisestä, epätavallisesta tai epäsopivasta suhteessa objektiiviseen, operatiiviseen, nykyaikaiseen maailmaan (elokuvassa kuvattujen tapahtumien tai kuvausten nykyaikaan). Tästä johtuen hieman sarjakertomusten Pariisin mysteeriä, marginaalia, "välitilaa" valuu hiljalleen kerrontaan... aivan niin kuin jokin, jäädäkseen tulkinnanvaraiseksi, ei olisi vielä löytänyt muotoaan ja tavanomaisia merkityksiään.

Sen lisäksi, että Rivette piti mykkäelokuvasta, voidaan nostaa esiin hänen (ja uuden aallon elokuvaohjaajien) arvostuksensa Jean Cocteauta kohtaan (tullessaan Pariisiin Rivetten ainoa manuaali elokuvan tekemiseen oli Cocteaun päiväkirja elokuvan Kaunotar ja Hirviö kuvauksista - Journal du tournage de Belle et la Bête). Cocteau, "välitilan" elokuvaohjaaja-runoilija, totesi salaperäisesti: "Nämä asiat ylittävät meidät, teeskennelkäämme, että olemme ne organisoineet" (ces choses nous dépassent feignons d'en être les organisateurs).

Osaltaan tämä vaikutelma johtuu kahden navan yhdistelmästä6 (muistakaamme, mitä Rivette sanoi Stockhausenista): "ääriorganisoitunut napa" kertoo täydellisestä hallinnasta, kun taas "antakaamme kaiken mennä omalla painollaan ja syntyä" -napa liitetään yleensä näyttelijöiden improvisaatioon. Tämä kahden navan yhdistelmä on toivottu ja välttämätön tuottamaan ne nyrjähdykset, joita Rivette etsii arkipäivän todellisuudesta. Näin siirrymme dokumentaarista johonkin fiktiota laajempaan, sillä oletus mahdollisesta ylittää fikton uskottavuuden.

\section{$\bullet \bullet$}

Elokuvan alusta alkaen mykkäelokuvan rekisteri muuttuu monimutkaisemmaksi. Sitä tukevat pitkät kohtaukset ilman dialogia. Puhe merkityksen julkituomisen paikkana on syrjäytetty (ironisesti Eustachen ja Truffaut'n elokuvissa kaikista puheliain näyttelijä, Jean-Pierre Léaud, on kuuromykkä); esiintyjät, harrastajateatterin näyttelijäseurueet, tekevät ilmavirran hallitsemiseen ja hengittämiseen liittyviä harjoituksia sekä esittävät pantomiimin keinoin vailla inhimillisiä sanoja maailman syntyajankohtaan liittyvää kaaosta. Jos he näyttävät parodioivan mykkäelokuvaa, eivätkö he ilveile myös erään ajankohdalle ominaisen puheliaan elokuvasuuntauksen kustannuksella (Truffaut, Eustache, Rohmer)? Rivette haluaa muistuttaa, että äänielokuvan aikanakaan elokuva ei ole kertovan puheen taidetta, se ei ole ennen kaikkea romaanikirjallisuutta jäljittelevää taidetta. Totta on, että elokuva on seurannut kyseistä narratiivista polkua (mukavuudesta tai taloudellisista syistä), mutta ne elokuvaohjaajat, jotka ovat asettaneet itselleen kunnianhimoisemmat tavoitteet, ovat etsineet lakkaamatta keinoja, joiden myötä elokuva voi kehittää omaa erityisyyttään ja tuottaa omaa ajatteluaan omien keinojensa pohjalta.

\section{$\bullet \bullet$}

Elokuva, joka ei ole tiukasti narratiivinen, realistinen, representatiivinen, on eräs modernin elokuvan keskeisistä pyrkimyksistä. Deleuze on tehnyt päämäärättömään kuljeskeluun perustuvasta muodosta - forme bal(l)ade -, joka perustuu elokuvan ky-

\footnotetext{
6 Serge Daneyn ja Jean Narbonin keskustelu Rivetten kanssa. Cahiers du cinéma n³23-324 (maaliskuu 1981).
} 
kyyn päästää irti kerronnasta puhtaasti visuaalisten tai ääneen perustuvien kuvien hyväksi, yhden modernin elokuvan olennaisista piirteistä.

Kuten Rivetten muissakin teoksissa, elokuvassa Out1 on kävellen tai autolla kuljettuja matkoja, joiden päämäärä hämärtyy ja jotka riittävät itsessään toimimaan merkitsijöinä. On myös muoto, joka on estetiikaltaan lähinnä tanssillinen, kehollinen tai jopa performatiivinen ja jonka myötä torit ja risteykset, kahviloiden terassit, aukiot tai julkiset puistot kioskeineen ja leikkialueineen liittyvät välttämättä Rivetten pariisilaiseen maisemaan. Näiden maisemallisten esiintymislavojen ansiosta, jotka rytmittävät kulkua kaupungissa, takaa-ajon tai jonkin asian tavoitteluun perustuva dramaturgia liukenee, tarina jää tauolle, minkään perässä ei varsinaisesti enää juosta: Quentin lähtee etsimään Renaud'ta ${ }^{7}$, asettuu erääseen risteykseen, jää pyörimään paikoilleen ja laskemaan askeleitaan aivan kuin olisi kirjaimellisesti toteuttamassa ranskankielistä populaaria ilmausta faire les 100 pas (astua sata askelta). Toisaalla haaveillaan, odotetaan, luetaan keskellä katua, pyöritään itsensä ympärillä, lauleskellaan. Kaupungin muoto, josta on tullut esityksen näyttämö, on erilainen, odottamattomampi ja hauskempi, täynnä reikiä ja rakoja. Se on vähemmän toiminnallinen, vähemmän dramaturginen, hetkelliseltä vaikuttava.

..."Kaupungin muodon" ajatus tulee Baudelairelta, joka toistaa runossaan Le Cygne (Joutsen) "Pariisi muuttuu". "Vanhaa Pariisia ei enää ole / kaupungin muoto / Muuttuu nopeammin, valitettavasti! kuin kuolevaisen sydän". Julien Gracq lainaa ilmaisua nuoruutensa aikaista Nantesia käsittelevässä teoksessaan La Forme d'une ville (Kaupungin muoto).

\section{$\bullet \bullet$}

Kaupungin muuttuva muoto on baudelairelainen ajatus. Elokuvassa Out1 se kohtaa balzacilaisen Pariisin juonteen, joka kehittyy ja katoaa L'Histoire des Treize-romaaniin liittyvän maininnan myötä. Katoaminen on myös kissalle annettu ominaisuus Lewis Carrollin romaanissa. Kuten Carrollin kissa, maininta Kolmentoista ryhmästä on salaperäisyydessään sitkeä merkitsijä.

\section{$\bullet \bullet$}

Rivette pyytää avukseen Eric Rohmerin, suuren Balzac-tuntijan, tulkitsemaan Balzac-asiantuntijan roolihahmon. ${ }^{8}$ Myös siksi, että Rohmer on aiemmin todennut itsestään ja Cahiers du Cinéma -lehden ystävistään: "Pidimme itseämme vähän kuin Kolmentoista ryhmän jäseninä ja tunsimme Balzacin miltei koko tuotannon ulkoa". ${ }^{9}$ Kolmentoista ryhmän merkityksen Balzac-asiantuntija selittää paradoksaalisesti sen katoamisella Balzacin tuotannosta! Liian ilmeisenä kolmentoista salaliittolaisen ryhmä alkaa häiritä kirjailijaa, sen on siis kadottava kasvattaakseen voimaansa! Rivetten elokuvassa katoava viittaus on tapa laimentaa salaisuuden ulottuvuutta,

\footnotetext{
7 Viidennessä episodissa "Colinilta Paulinelle" (minuutit 113-120).

8 Kolmannen episodin "Frédériquelta Sarah'lle" alussa. Kohtaus tuo yhteen kuuromykän Colinin (Jean-Pierre Léaud) ja Balzac-asiantuntijan, joka kommentoi työhuoneessaan romaania Histoire des Treize.

9 Johdanto Balzacin romaaniin La Rabouilleuse (1992). "Lignées balzaciennes, par Eric Rohmer" (Eric Rohmer: Balzacilaiset sukulinjat). POL, 17.
} 


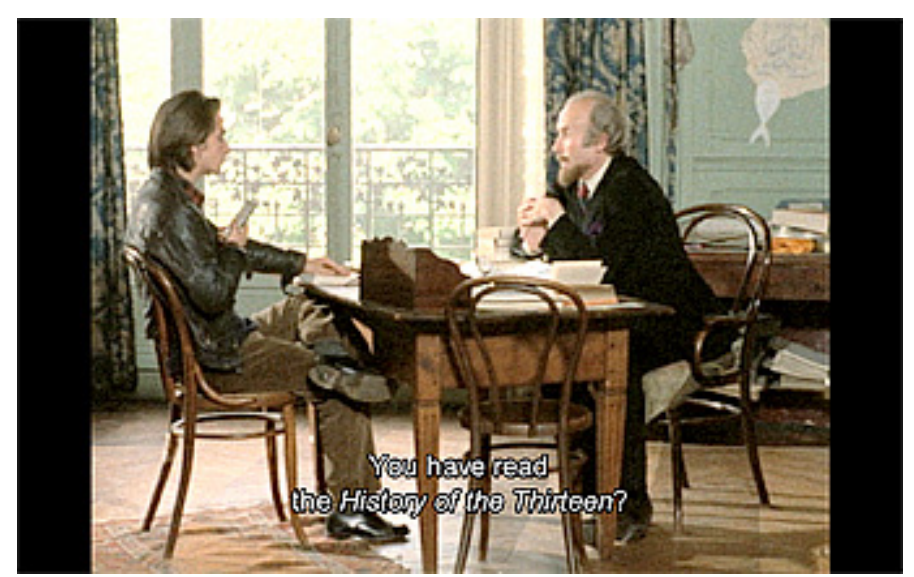

Elokuvassa Out1 Pariisi kohtaa balzacilaisen Pariisin juonteen, joka kehittyy ja katoaa L'Histoire des Treize -romaaniin liittyvän maininnan myötä. Kuva: kuvakaappaus elokuvasta.

joka lakkaa olemasta dramaturgian romanttinen, poliittinen tai sosiologinen jousi. Se jää ympäröimään maailmaa tästä lähtien sen ulkopuolelta - out.

Näin Rivette vastaa kysymykseen, joka korosti jälleen kerran salaliiton teemaa hänen elokuvissaan:

Jotakin on piilossa, olemme kaikki yhtä mieltä asiasta [...] Salaliiton teema on veruke. Se on aihe, joka on tehty paloiteltavaksi [...] On luettava tarkasti Balzacia huomatakseen, mistä on kysymys, sillä kyseessä on salaperäinen kirjailija, joka kätkee todella tärkeät asiat.

Se, mikä teki tärkeää poispyyhittyyn salaliittolaisten ryhmään turvautumisesta, on nyt puolestaan epäselvää ja täsmentymätöntä... out.

\section{$\bullet \bullet$}

Salaisuus ympäröi maailmaamme. Jos se on vaikeasti luettavissa, kyseinen salaisuus liittyy elokuvan organisaatioon ja sen work in progress -tyyppiseen toteutukseen, sillä tämä malli edeltää tai ennakoi merkityksen saamaa lopullista muotoa. Suurin osa Rivetten elokuvista on hämäriä, samaan aikaan, kun niiden kutkuttava muoto synnyttää toiveen merkityksestä, saa vaatimaan tulkintaa, joka on yleensä eriaikainen.

Out1 näyttää olevan syvällinen luenta Roland Barthesin haastattelusta. Eräässä vaiheessa kirjailija puhuu Brecht-kokemuksestaan (joka tekee Rivetten elokuvien suhteen teatteriin huomattavasti monimutkaisemmaksi). Barthes lausui:

Muistan että Brecht ehdotti meille Théâtre Populairessa vaihtojen organisoimista [...] tämä tarkoitti mielikuvitusnäytelmän toteuttamista, jossa toisiaan seuraavat kohtaukset olisivat kuin osa shakkipeliä; joku luo peliin jonkin tilanteen, toinen valitsee sitä seuraavan tilanteen $[\ldots]$

Tästä ohjeesta ilmenee keston, akkumulaation, näkökulmien ja tapahtumien moninkertaistumisen tärkeys elokuvassa, mutta myös ja samanaikaisesti näyttelijöiden 
monipuolinen osallistuminen sekä tästä osallistumisesta aiheutuvat haarautumat, pysäytykset, toisin sanoen muotoon ja aikaan liittyvä labyrintti, josta teos nousee esiin. Tuloksena on aikaansaannos, joka on vähemmän järjestelmällinen kuin kekseliäs tai hypoteettinen ja joka on kiinni salaisesti arvattavissa, taipuilevissa polvekkeissa. Kyse on tietoisesti paljastetusta merkitsijän tekniikasta, ennemmin kuin merkityksen jakamisesta.

Barthes jatkaa kuitenkin antaen mahdollisuuden pohtia toisella tapaa merkitystä ja yleistä tavoitetta ohi itse elokuvan muodostamien raamien:

Brechtillä oli kirkas käsitys merkityksen tekniikoista [...] merkitsijöiden vastuullisuudesta [...] ja luonnollisesti koko tämä tekniikka oli ajateltu kokonaisuudessaan poliittisen ajattelun näkökulmasta. Poliittisen ajattelun näkökulmasta mutta ei ehkä poliittista ajattelua varten; ja tässä kosketamme brechtiläistä tulkinnanvaraisuutta; pohdin, eikö Brechtin [poliittisesti] sitoutunut merkitys ole lopultakin omalla tavallaan merkitys odotuksen tilassa [...]: annettakoon teokselle tehtäväksi kysyä kysymyksiä (kirjailijan valitsemin termein, koska kyseessä on vastuullinen taide), ja yleisölle löytää vastauksia $[\ldots]$ tekstissä on selvästikin vahva merkitys, mutta tuo merkitys on aina kysymys [...] Se selittää miksi tämä kriittinen, poleeminen, sitoutunut teatteri ei ole militanttia teatteria.

Nämä rivit on mahdollista kääntää koskemaan Rivetten työtä ja todeta, että hän luo elokuvaa, jossa merkitys on "odotuksen tilassa". Odottava merkitys ei palvele tyhjiä muotoon liittyviä kokeita vaan avoimesti poliittisia tarkoitusperiä (polis, polites, joka koskettaa kaupunkia ja sen asukkaita). Rivetten elokuvien johtoajatuksena on idea-muoto politiikasta, jonka olemassaolo on tunnistettava ja luotava kollektiivisesti. 